\title{
ALCANCE
}

\section{O DARK SIDE DAS NARRATIVAS NA PUBLICIDADE: A EXPLORAÇÃO DE TRAGÉDIAS E ATROCIDADES EM PEÇAS PUBLICITÁRIAS}

THE DARK SIDE OF NARRATIVES IN PUBLICITY: EXPLORING TRADGEDIES AND ATROCITIES IN PUBLICITY TEXTS

EL DARK SIDE DE LAS NARRATIVAS EN LA PUBLICIDAD: LA EXPLORACIÓN DE TRAGEDIAS Y ATROCIDADES EN PIEZAS PUBLICITARIAS

MAÍZY CASSIA SILVA

Mestra

Universidade Federal de Uberlândia - Brasil Instituto Federal do Triângulo Mineiro

ORCID: 0000-0001-7327-6807

maizycassia@hotmail.com

CINTIA RODRIGUES DE OLIVEIRA MEDEIROS

Doutora

Universidade Federal de Uberlândia - Brasil

ORCID: 0000-0001-7999-9002

cintia@ufu.br

ANDRÉ FRANCISCO ALCÂNTARA FAGUNDES

Doutor

Universidade Federal de Uberlândia - Brasil

ORCID: 0000-0003-1177-4514 andre.fagundes@ufu.br

INDEXED BY

Submetido em: 27/11/2017

Aprovado em: 11/09/2019

Doi: 10.14210.alcance.v26n3(set/dez).p363-381

LCENÇA CC BY:

Artigo distribuído

sob os termos

Creative Commons,

permite uso $\mathrm{e}$

distribuição irrestrita

em qualquer meio

desde que o autor

credite a fonte

original.

(c) (i) 


\section{RESUMO}

Neste estudo, nosso objetivo é explorar o modo como as organizações gerenciam os significados de tragédias e atrocidades externas a elas em campanhas publicitárias para atingir seus objetivos. A pesquisa é de natureza qualitativa, com suporte no paradigma interpretativista. Para compor o material empírico, selecionamos seis propagandas divulgadas nas mídias, em vídeos ou em cartazes, por organizações de diferentes tipos. Para alcançar nosso objetivo, realizamos a análise estrutural-semiológica do material selecionado para avaliar como textos e imagens são empregados na construção das propagandas. Como resultados, identificamos os significados: "castigo para a obesidade", "ser feliz na guerra", "não às armas", "informação é vida", "descanso em tempos de terror" e "morte e solidariedade". Ainda, apontamos que fenômenos trágicos são aproximados do contexto organizacional, e as organizações exibem capacidades e habilidades para interagir com tais atrocidades e tragédias, bem como gerenciar o seu significado sombrio, por meio de narrativas e estratégias discursivas, para alcançar seus objetivos corporativos.

Palavras-chave: Dark side; Propaganda; Gerenciamento de imagem.

\section{ABSTRACT}

This aim of this research is to investigate how organisations manage the meanings of external tragedies and atrocities in publicity campaigns to achieve their goals. It follows a qualitative approach based on an interpretative perspective. Six campaigns from different organisations and displayed in different media, such as videos and posters, were selected as empirical data. A structural-semiotic content analysis was performed on the selected data to assess how texts and images were used in the design of the advertisements. As results, we identified the following meanings: "punishment for obesity", "to be happy in war", "no to weapons", "information is life", "rest in times of terror", and "death and solidarity". We argue that such tragic phenomena were close to the organizational context, and that organisations displayed expertise and skills to interact with such atrocities and tragedies, as well as to manage their dark meaning through narratives and discourse strategies, in order to fulfil their corporate objectives,

Keywords: Dark side; Publicity campaign; Image management.

\section{RESUMEN}

En este estudio, nuestro objetivo es explorar el modo cómo las organizaciones administran los significados de tragedias y atrocidades externas a ellas en campañas publicitarias para alcanzar sus objetivos. La investigación es de naturaleza cualitativa, con soporte en el paradigma interpretativista. Para componer el material empírico, seleccionamos seis propagandas divulgadas en los medios, en videos o en carteles, por organizaciones de diferentes tipos. Para alcanzar nuestro objetivo, realizamos el análisis estructural-semiológico del material seleccionado para evaluar como textos e imágenes son empleados en la construcción de las propagandas. Como resultado, identificamos los significados: "castigo para la obesidad", "ser feliz en la guerra", "no a las armas", "información es vida", "descanso en tiempos de terror" y "muerte y solidaridad". Aún, apuntamos que fenómenos trágicos son aproximados del contexto organizacional, y las organizaciones exhiben capacidades y habilidades para interactuar con tales atrocidades y tragedias, bien como administrar su significado sombrío, por medio de narrativas y estrategias discursivas, para alcanzar sus objetivos corporativos.

Palabras-clave: Dark side; Propaganda; Administración de imagen. 


\section{INTRODUÇÃO}

Eventos extremos, desastres, tragédias e atrocidades têm figurado de forma frequente nos noticiários nacionais e internacionais, chamando atenção para suas causas, como o aquecimento global e mudanças climáticas e também ações humanas, e suas consequências, como mortes, destruição de comunidades, comunidades desabrigadas, entre outras (Tavares, 2013; Barbosa, 2018; Pinheiro, 2019).

Em um contexto em que a mídia está cada vez mais presente e atuante, atrocidades e tragédias tendem a chamar a atenção da população em geral, incluindo grupos de interesse das organizações e os seus consumidores. Conforme especialistas, a propagação massiva e excessiva dessas imagens, em vez de tornar as pessoas mais sensíveis, acabam por torná-las indiferentes e até mesmo insensiveis (Brandão, 2019), pois o ser humano é, naturalmente, atraído por imagens. Tragédias, no sentido figurado, são acontecimentos funestos, trágicos, terríveis, independentemente de sua causa, podendo essa ser natural ou provocada pela ação humana. Já atrocidades são atos humanos caracterizados pela crueldade e perversidade.

A despeito de suas consequências, Muhr e Rehn (2014) afirmam que, para as organizações, acontecimentos trágicos podem ser formas eficazes de mobilizar a consciência de consumidores sobre questões gerais das tragédias ou atrocidades ou sobre as próprias organizações, pois são fatos que chamam a atenção das pessoas, seja pela grande divulgação na mídia ou por uma mobilização emocional em relação ao acontecido.

É cada vez mais frequente as organizações gerirem as imagens de tragédias e atrocidades, externas à organização, de forma estratégica para seus próprios fins, tornando esses fatos uma mercadoria simbólica, que poderá transmitir um conteúdo associado à imagem, à marca ou à mensagem. Contudo, esse uso pode ter consequências negativas, como associações à exploração desses acontecimentos.

Nesse sentido, Muhr e Rehn (2014) apontam para a presença de um lado sombrio - dark side - nas organizações, pela utilização de tragédias e atrocidades para desenvolver ações com fins mercadológicos. Vince e Mazen (2014) sugerem que uma razão para estudar esse lado sombrio das organizações é desenvolver uma compreensão mais apurada a respeito das emoções e das políticas que são essenciais para as organizações, bem como o seu impacto sobre os pensamentos das pessoas e suas interações no ambiente organizacional.

O lado sombrio das organizações, normalmente, é tratado como algo a esconder e manter sob controle, evidenciando que existe uma lacuna na exploração desse aspecto das organizações por parte da academia, sendo, portanto, um tópico a ser mais bem explorado (Linstead, Marechal, \& Griffin, 2014).

Um dos tópicos relacionados ao dark side que chama atenção é a utilização de tragédias e atrocidades externas, que não são de responsabilidade específica das organizações, como recurso mercadológico. O lado sombrio se expressa, nesse sentido, quando organizações se aproveitam dessas tragédias de forma oportunista, na tentativa de disseminar uma imagem de apoio. Muhr e Rehn (2014, p. 226) mencionam que "organizações usam de forma organizada fenômenos sombrios para promover seus próprios fins e fazem isso a partir de uma posição (potencialmente) publicamente aceitável". Dessa forma, mesmo utilizando fatos obscuros para promoção da sua imagem, a ação das organizações tem, de acordo com Linstead, Marechal e Griffin (2014), uma aceitação pública, desde que a situação (tragédia) seja gerenciada de forma adequada e coerente com a imagem que se deseja passar.

Nesse contexto, normalmente, as organizações utilizam tragédias como forma de captar e mobilizar a atenção do público de interesse, assim as atrocidades, de acordo com Muhr e Rehn (2014), são colocadas como recursos organizacionais para serem utilizados como materiais que, ao serem associados à marca ou à organização, podem chamar à atenção do espectador. No entanto, segundo os autores, pouco se discute na literatura sobre como o significado simbólico das atrocidades é gerido, ou seja, como ela são selecionadas, encenadas e narradas, a fim de estar de acordo com uma imagem ou com outras metas organizacionais. Os autores afirmam que a gestão de significado e símbolos desempenha um papel cada vez mais importante na atual sociedade, uma vez que a marca não está mais limitada a comunicar fatos sobre um produto específico, mas, sim, tornar-se um objeto complexo, performativo e relacional, que interage com o contexto social.

Neste artigo, nosso objetivo é explorar de que modo as organizações gerenciam os significados de tragédias e atrocidades externas em campanhas publicitárias para atingir seus fins. Para alcançar esse objetivo, buscamos descrever e interpretar as construções de narrativas instituídas em torno dos símbolos expostos, utilizando a análise de fotografias e de filmes, de seis propagandas divulgadas na mídia por organizações que utilizaram acontecimentos trágicos, com grande impacto na sociedade (em nível nacional e internacional), para divulgar objetivos próprios.

Estruturamos o artigo da seguinte forma: em primeiro momento, apresentamos a fundamentação teórica a respeito do dark side e gerenciamento de imagem, incluindo o gerenciamento de tragédias e atrocidades. Em seguida, 
descrevemos o método para análise explicando suas peculiaridades, apresentamos e discutimos as propagandas e as análises relativas a cada uma. Por fim, apresentamos as considerações finais geradas a partir dos resultados e as suas relações com a teoria, além de sugestões para estudos futuros.

\section{QUE EXISTE NO LADO SOMBRIO DAS ORGANIZAÇÕES}

De acordo com Linstead, Marechal e Griffin (2014), o campo dos estudos organizacionais apenas recentemente começou a implantar a metáfora do dark side organizacional, ou seja, considerando o lado sombrio para perceber e ressaltar uma nova preocupação com os assuntos que têm sido tradicionalmente negligenciados, ignorados e suprimidos dentro das organizações e em ambientes acadêmicos pelas teorias organizacionais. Isso porque, segundo os autores, 0 contexto organizacional geralmente é observado e analisado sob um ponto de vista gerencialista e positivista, ressaltando, na maioria dos casos, somente ações desenvolvidas dentro de padrões e que são deixadas à mostra.

Em outros campos de conhecimento, como na área de psicologia, estudos sobre liderança e carisma (Hogan, 1990), também consideram o seu dark side, no entanto se trata de uma visão focada no lado negativo dos fenômenos, sem reconhecer que se encontram nos limites e nas práticas organizacionais. No empreendedorismo, o dark side se manifesta nos traços de personalidade e nos comportamentos de empreendedores que, embora lhes permitam ser bemsucedidos nos negócios, são prejudiciais no desempenho de suas funções como gerentes ou mesmo como colegas de trabalho (Vries, 1985; Khan, Munir, \& Willmott, 2007). Vaughan (1999) afirma que, habitualmente, as mesmas características de um sistema que produzem o lado que brilha (transparente) poderá regularmente provocar o lado sombrio ao longo do tempo. Sendo assim, esse lado sombrio pode fazer parte das ações e dos processos organizacionais, bem como pode não ser construído intencionalmente, mas como resultados de ações e comportamentos frequentes. Além disso, também pode não haver uma intenção sombria, mas possuir características que contribuam para o lado sombrio.

Além dos estudos organizacionais, outras áreas da administração passaram a se interessar pelo dark side, por exemplo, Boddy (2006), que tratou do dark side das tomadas de decisão, e a área de marketing, que, a partir da primeira década deste século, passou a explorar o lado sombrio do marketing, contrastando com a perspectiva dominante das representações tradicionais de clientes e membros organizacionais como entidades funcionais e orientadas para o bom funcionamento da sociedade (Daunt \& Greer, 2017). Esse interesse culminou em uma edição especial do Journal of Marketing Management, em 2017, cujas publicações focalizam as complexidades, as contradições e as consequências de comportamentos desviantes adotados por consumidores e membros da organização, como empregadores e empregados (Carr \& Schrereur, 2010; Pancer, Mcshane, \& Poole, 2017; Weeks, O'connor, \& Martin, 2017; Heath, Culley, \& O'malley, 2017; Zolfagharian, \& Yasdanparast, 2017; Golf-Papez, \& Veer, 2017; Dootson et al., 2017).

No entanto, o que Linstead, Marechal e Griffin (2014) apontam é que as duas últimas décadas têm apresentado um reconhecimento de que o lado sombrio não é um escuro outside, um fenômeno localizado do lado de fora das organizações que colide com a ação organizacional, mas, sim, um interior sombrio, encontrado dentro dos limites e das práticas organizacionais. Para os autores, normalmente, as ações organizacionais e sociais seguem determinados padrões e normalizações definidos pela sociedade, no entanto existem, na maioria das situações, práticas sombrias que muitas vezes são suprimidas diante de uma visão funcionalista. Neste contexto, os autores colocam que se tem dado ênfase em aspectos sociais do comportamento, a respeito das ações disfuncionais, antiéticas, antissociais e repreensíveis consideradas como estranhas ou anormais e que precisam de "correção", uma vez que, aos olhos da sociedade em geral, são comportamentos desviantes, sendo eles ilegais ou não. Vale ressaltar, neste contexto, que nem sempre são ações consideradas erradas ou ruins, mas sim ações que estão à sombra das organizações e dos estudos, ou seja, não mencionada e nem analisadas normalmente, por serem consideradas possuidoras de algum desvio do que é tido como habitual.

O lado sombrio não é exclusividade de empresas do ramo privado. Todas as formas organizacionais e atividade de uma organização apresentam essas características, uma vez que todas possuem processos que são geridos por pessoas (Linstead, Marechal, \& Griffin, 2014). Especificamente quanto às atividades de marketing organizacional, de acordo com Muhr e Rehn (2014), o lado sombrio também pode ser observado sob a ótica de ações que se colocam em contradição com o habitual. Em muitos desses casos, ainda na visão de Muhr e Rehn (2014), as formas de comunicação adotadas são seguidas de mensagem com interpretações ambíguas, em alguns casos, e que abordam algum tema sombrio da sociedade, se contrapondo aos modelos informativos, humorados e sentimentalistas, que comumente são adotados pelas organizações.

O marketing de tragédias e atrocidades, no contexto aqui analisado, não se enquadra nas categorias destacadas por Linstead, Marechal e Griffin (2014) do lado sombrio, visto por dois aspectos: aqueles que prejudicam os outros ou 
que prejudicam a organização, uma vez que as tragédias e as atrocidades em si não são de responsabilidade das instituições que as usam como forma de propaganda. Nesse caso, elas são apenas utilizadas como um modo de captar a atenção de um público específico por meio da associação de uma mensagem estratégica. No entanto, para Muhr e Rehn (2014), o uso dessas tragédias e atrocidades como forma de comunicação de objetivos específicos foge das abordagens tradicionais, evidenciando o uso de acontecimentos sombrios da sociedade em prol de fins particulares, 0 que em alguns casos pode ser considerado como antiético ou visto como forma de aproveitamento e exploração.

\subsection{SIGNIFICADOS E MENSAGENS SIMBÓLICAS}

Cada organização possui seus processos, práticas e suas formas de agir e se posicionar diante da sociedade. Ao se posicionarem, as organizações produzem símbolos e significados, de forma consciente ou não, que vão influenciar a construção da realidade (GIOIA, 1986). Por exemplo, organizações utilizam-se de storytellings em campanhas publicitárias para associar seus produtos e sua marca à felicidade (Martins \& Medeiros, 2017; Witzki, Prado Junior, \& Cardoso, 2017) por meio de simbolismos, como fantasia e magia.

Essas ações, além de serem vistas e desenvolvidas pelos membros internos a essa organização, também podem ser observadas pelos membros externos a ela. Hatch e Schultz (2002) mencionam que a imagem organizacional se refere ao conjunto de pontos de vista sob a organização que são sustentados por aqueles que agem como "outros" da organização, ou seja, os que são externos a ela. Assim, a imagem da organização refere-se ao modo como ela é vista pelos componentes da sociedade. Os autores diferenciam imagem e identidade, porém alertam para a relação entre os dois termos: "a ligação entre a fronteira interna e externa estabelece que a gestão da identidade corporativa envolva a formulação e comunicação da visão organizacional e da estratégia em referência à imagem externa. Sendo assim, 0 gerenciamento da identidade e da imagem é um processo interligado" (Hatch \& Schultz, 1997, p. 363).

De acordo com Hatch e Schultz (2000), na compreensão da imagem organizacional, não significa que ela é interpretada da mesma forma que foi criada, assim, podem haver divergências nesse processo, e, em muitos casos, a imagem vista não é condizente com a real intenção organizacional. Por esse fato, faz-se necessário o gerenciamento adequado dessa imagem. Barbosa (2008) afirma que, cada vez mais, a imagem pode se constituir como uma variável estratégica para as organizações no local e na forma em que elas se estabelecem. Por exemplo, Scussel e Dellagnelo (2018) discutem o papel da publicidade para uma reinterpretação do modo como olhar o corpo obeso, livre de estereótipos e estigmas, analisando se as representações sociais nas campanhas publicitárias de lingerie no Brasil contribuem para 0 ativismo plus size.

A propaganda e outras formas de comunicar mensagens e ações realizadas em torno da marca são processos do gerenciamento da imagem organizacional. Nesse contexto, há um grande trabalho organizacional, com dispêndio de tempo e financeiro em relação à construção de um simbolismo que associe o que é transmitido à imagem que a organização quer transmitir. Para Boyce (1996), o simbolismo organizacional envolve a construção de significado em organizações, sendo os símbolos compartilhados por meio de histórias e narrativas, que podem ser atreladas a imagens que vão transmitir o conteúdo desejado. De acordo com Jatahi (2004), os símbolos e a criação do simbolismo servem como pontes, tornando administrável a ambiguidade inerente à situação e, nesse caso, a linguagem assume função persuasiva, retórica, orientada para a construção de significados.

Imagens são utilizadas na publicidade para manipulação comercial (Featherstone, 1995), pois, ao expor cenas da vida cotidiana, reativa desejos no público-alvo, persuadindo consumidores de forma consciente ou não. 0 simbolismo em propagandas é apropriado pelo consumidor, cujo comportamento é influenciado pelo discurso estabelecido pelas imagens e seus elementos textuais (Silva \& Chaves, 2017). Ao analisar as propagandas do setor supermercadista de varejo, Silva e Chaves (2017) identificaram a persuasão em dois tipos de racionalização: sentimento e pensamento, os quais procuram induzir associações afetivas às imagens. Witzki, Prado Júnior e Cardoso (2017, p. 133, grifos nossos) observam que no cotidiano de nossas vidas somos "surpreendidos por momentos que captam - e raptam - nossa atenção, fazendo com que esqueçamos, momentaneamente, da nossa ordinariedade da vida (por vezes para o bem, outras, para o mal) para momentos singulares, singelos, prosaicos, como os provocados pela campanha analisada."

Diante da relevância da gestão de significados, e dos investimentos pelas empresas nessa gestão, Muhr e Rehn (2014) afirmam que a marca não está mais limitada a comunicar fatos sobre um produto específico, mas, sim, é um objeto complexo, performativo e relacional promotor de contextos. É nessa direção que os autores afirmam que, para as organizações, acontecimentos trágicos podem ser formas eficazes de mobilizar a consciência de consumidores sobre questões gerais ou sobre si próprias, contudo os autores apontam que pouco da literatura discute como o significado simbólico da atrocidade é gerido, ou seja, como as tragédias ou as atrocidades são selecionadas, encenadas e narradas, a fim de se tornarem coerentes com a imagem organizacional ou com outras metas organizacionais (Muhr \& Rehn, 2014). 
Assim, Muhr e Rehn (2014) também afirmam que a gestão do enredo específico em campanhas tornou-se importante, o que leva a acreditar que não é suficiente afirmar que atrocidades podem ser usadas apenas como materiais de branding, mas que se deve investigar como as atrocidades e as tragédias são geridas e narradas, sendo classificadas como recursos organizacionais.

Barbosa (2008) afirma que se pode considerar a imagem um fator inacabado, passível de alterações e de acréscimo de informação, podendo mudar seu significado simbólico em função de como as mensagens são recebidas e percebidas, portanto é possível de ser gerenciada. É nesse contexto que as imagens ligadas a tragédias e atrocidades se tornam recursos organizacionais que são trabalhados para adquirirem um simbolismo ligado à imagem organizacional que se deseja transmitir.

Para Freitas (2000), as organizações captam as possiblidades do ambiente e respondem não apenas de maneira operacional, mas, também, de modo simbólico, via cultura organizacional e repasse de todo um imaginário. Nesse contexto, Muhr e Rehn (2014) apontam, como exemplo, que narrativas e imagens de dor pessoal, associadas a tragédias ou a atrocidades, podem ajudar as organizações a comunicar uma imagem ética a seus clientes e a suas comunidades, estimulando imagens desejadas para serem reproduzidas entre as partes interessadas, por meio do simbolismo.

Para Muhr e Rehn (2014), a discussão de atrocidades de branding deve ser entendida de modo que a marca não se constitua apenas em uma ferramenta de marketing, mas, também, que essa esteja profundamente enraizada na identidade e na imagem organizacional e que comporta significados socialmente relevantes, que as organizações buscam gerenciar dentro de um lado sombrio.

\section{PROCEDIMENTOS METODOLÓGICOS}

A pesquisa, de natureza qualitativa, apresentou suporte no paradigma interpretativista. Para a coleta do material empírico utilizamos, por conveniência, um sistema de buscas on-line (Google), pesquisando pelos seguintes termos: "publicidade/propaganda e tragédia/atrocidade". Como resultado, encontramos cinco sites (Hypescience, Revista Exame, Businessinsider, Bhaze e Adnews), que apresentaram listas ou comentários a respeito de propagandas que, de algum modo, fazem alusão a tragédias ou atrocidades.

Desconsiderando as citações repetidas, nós encontramos 31 propagandas. A partir desse total, selecionamos 6 diferentes tipos de propagandas (Figura 1), em vídeos ou em formato de cartazes (imagens paradas), divulgadas nas mídias por organizações empresariais ou não. Como critério para seleção, optamos por propagandas com textos ou vídeos completos, e que fossem claras quanto a sua intenção, não apresentando ambiguidade na mensagem, o que resultou em seis propagandas. Também optamos por propagandas que utilizaram grandes tragédias ou atrocidades atentando contra a vida humana, com vinculação midiática nacional ou internacional, de modo a atender o objetivo da pesquisa, que pretende explorar o uso de tragédias e atrocidades na publicidade. As propagandas foram notadas e "experimentadas" por um contexto abrangente, além disso, são consideradas tragédias e atrocidades externas, segundo a visão apresentada por Muhr e Rehn (2014), aquelas que não foram provocadas ou possuíram participação direta das organizações que a utilizam em suas propagandas. A Figura 1 apresenta as propagandas analisadas neste estudo e suas respectivas fontes.

\begin{tabular}{|l|l|}
\hline Propaganda & Fonte \\
\hline Academia de Dubai e Holocausto & hypescience.com \\
\hline Rede Sainsbury's e I Guerra Mundial & hypescience.com \\
\hline Anistia Internacional e Tsunami & adnews.com.br \\
\hline Jornal Cape Times e Bomba Atômica & adnews.com.br \\
\hline Ortobom e atentado às Torres Gêmeas & hypescience.com \\
\hline Governo de Minas e rompimento da barragem em Mariana/MG & bhaz.com.br \\
\hline
\end{tabular}

Figura 1. Propagandas analisadas

Fonte: Elaborada pelos autores (2016).

Assim, a unidade de observação são os textos, as narrativas e as imagens das propagandas, observando não só os fatos, mas, também, as histórias construídas em torno deles. Para análise do material empírico, consideramos a construção narrativa em torno da imagem da tragédia ou da atrocidade divulgada, utilizando a análise estrutural semiológica (Longo \& Marita, 2014) para avaliar como textos e imagens são empregados na construção de propagandas. 
Para operacionalizar a análise, nos orientamos por Bauer e Gaskell (2002) e consideramos as duas dimensões das propagandas: imagens e texto, de uma forma integrada, porém, em um primeiro momento, nos valemos de inventários denotativos e conotativos, buscando interpretar os significados das imagens ancoradas pelos textos que as acompanham. Conforme Penn (2002, p.319), "a semiologia provê ao analista com um conjunto instrumental conceitual para uma abordagem sistemática dos sistemas de signos, a fim de descobrir como eles produzem sentido". Segundo a autora, a semiologia nasceu da obra linguística de Saussure (1857-1913) e compreende unidades que são denominadas de signos e as regras que governam suas relações, sendo considerada a ciência dos sistemas de significação.

Para Magalhães e Paula (2016), os signos linguísticos são imbuídos de significados que são dados, a priori, até serem (re)significados. Diante disso, Barthes (2006) destaca que uma maneira de análise entre os diferentes níveis de significação é o denotativo, ou primeiro nível, e literal, enquanto que, em um nível mais alto e mais arbitrário, é o conotativo e depende de convenções culturais.

Penn (2002) aponta que, na imagem publicitária, a mensagem denotativa ou literal serve para naturalizar a mensagem conotada, ou seja, o trabalho de interpretação, ou a compreensão da conotação da imagem, é mantido oculto e coeso pelo sintagma da denotação. Para a autora, a tarefa do semiólogo é desmistificar esse processo de naturalização, chamando a atenção para a natureza construída da imagem. Assim, Penn (2002) considera três níveis de significação: denotação (plano de expressão), conotação (significações) e mito (crenças resistentes a evidências empíricas). Esse último, para Penn (2002, p. 324), é "o meio pelo qual uma cultura naturaliza ou torna visível suas próprias normas e ideologia". Seguindo essa orientação, nós analisamos o material nos três níveis: (1) denotativo, que se refere ao que, objetivamente, a propaganda expressa; (2) conotativo, que são os significados interpretados das propagandas, ou seja, os significados que elas disseminam; e (3) os mitos, que representam as crenças culturais.

Barthes (2006) justifica o uso da propaganda com objetivos didáticos baseado no pressuposto de que os signos da publicidade são intencionais e serão, por isso, claramente definidos ou compreendidos. No caso do uso das tragédias e das atrocidades, deve-se considerar o fato de que a utilização de uma imagem ou de um acontecimento não está diretamente ligado ao que se quer divulgar, desse modo, a compreensão deve ser mais aprofundada para efetivar a ligação entre a imagem e o texto com a significação.

\section{SIGNIFICADOS DAS TRAGÉDIAS E DAS ATROCIDADES NAS PROPAGANDAS ANALISADAS}

As propagandas selecionadas foram analisadas sobre um inventário denotativo, evidenciando os principais aspectos aparentes e literais em cada situação. Na sequência, realizamos uma análise sob a ótica conotativa, buscando as significações dependentes de convenções culturais e das narrativas criadas a partir dos aspectos literais. Destacamos que para cada propaganda buscamos identificar os principais elementos que relacionavam os objetivos da organização ao uso da tragédia e da atrocidade na atividade de comunicação.

\subsection{CASTIGO: CAMPO DE CONCENTRAÇÃO NAZISTA PARA ELIMINAÇÃO DE CALORIAS}

A primeira propaganda a ser analisada foi publicada pelo Centro Fitness Circuit Factory de Dubai, publicada em 2012 em uma mídia social da empresa (Facebook), cujo significado é: A propaganda apresenta uma imagem como elemento central, evidenciando uma estrada de ferro, sem a presença de pessoas, que conduz ao campo de concentração Auschwitz, operado pelo Terceiro Reich na Alemanha Nazista. A imagem é apresentada em preto e branco, em um fundo escuro que the confere destaque. Acima dessa imagem é colocada a logomarca da empresa (The Circuit Factory), que, além do nome, exibe duas figuras representando pessoas se exercitando. Abaixo da primeira imagem é apresentado 0 slogan com a seguinte frase: "Dê um beijo de adeus às suas calorias" (tradução nossa) e o site para acesso e contato com 0 centro fitness - Figura 2. 


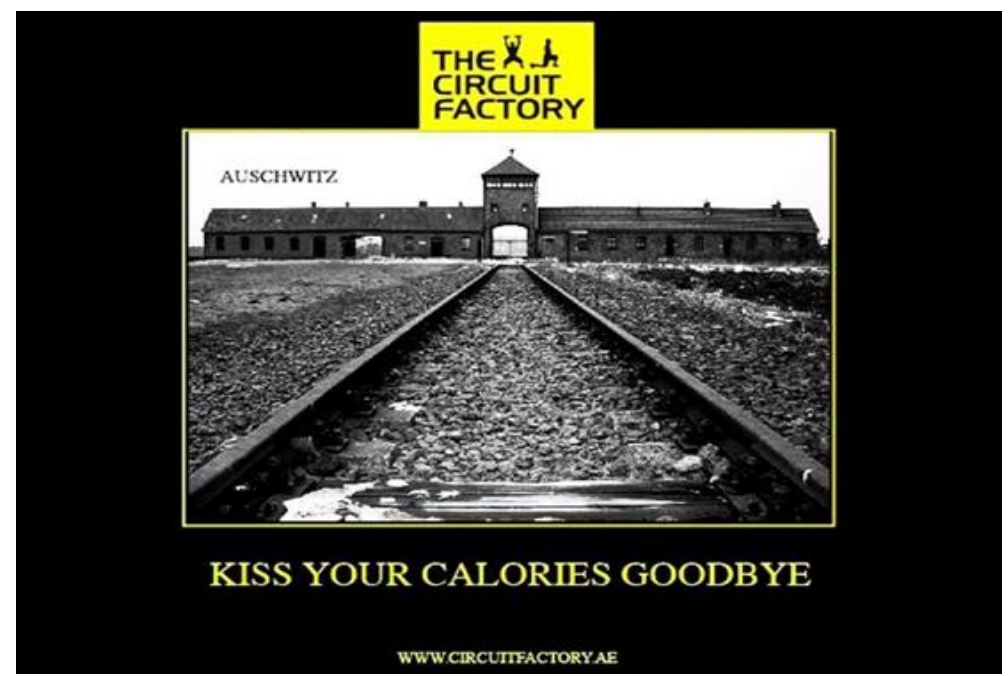

Figura 2. Propaganda da empresa The Circuit Factory

Fonte: Hypescience (2016).

O contexto da imagem associada à logomarca e ao texto remete a uma narrativa de caminhada a um centro de exercícios físicos, representado pelo campo de concentração, onde o foco absoluto seria a perda - extermínio - de calorias, o que é evidenciado pelo texto "adeus às suas calorias" (tradução nossa). 0 conjunto remete a um treinamento intensivo e constante que levaria a uma grande perda de calorias e gordura corporal. No entanto, essa associação criada com um campo de concentração Nazista como forma de promoção própria pode ter uma interpretação ofensiva em relação ao sofrimento que circunda o Holocausto. A imagem central utilizada na propaganda traz, explicitamente, uma cena que liga aos acontecimentos que rodeiam o Holocausto, evidenciando atrocidades e sofrimento. Somente com a observação da marca referente à empresa que promove a propaganda, e o texto que segue a imagem, é possível a relação com uma academia para exercícios físicos. Sendo assim, a associação proposta pela propaganda não é percebida em primeiro momento.

Além disso, a ligação a um campo de concentração, na nossa interpretação, remete ao sofrimento intenso ao realizar as atividades físicas com associações de privação e sacrifício. A interpretação também pode conter uma ligação à construção social em torno da obesidade e do sobrepeso como algo em não conformidade, fora dos padrões "fitness" estabelecidos socialmente, assim como as representações de não conformidade dos judeus frente à Alemanha Nazista.

De acordo com o jornal The National (2012), a imagem foi retirada da rede social e, logo após, o responsável emitiu um pedido de desculpas, afirmando que a intenção era apontar ideias fortes, e não ofender alguém. Ainda segundo o jornal, após o pedido de desculpas, a academia realizou uma doação originária dos lucros de aulas a uma associação de caridade filiada à Associação de Refugiados Judaicos. Segundo o Hypescience.com (2014), onde a propaganda foi encontrada, em primeiro momento, após o incidente, a academia informou aumento considerável no número de clientes, recebendo ainda um impulso nos negócios.

Todavia, para alcançar esse resultado financeiro aparentemente positivo, a empresa adotou e, de certa forma, enalteceu um crime da humanidade realizado em um contexto racista e homofóbico. Portanto, entendemos esse como um exemplo do dark side das organizações, cujos "fins justificam os meios", mesmo que para tanto se utilize de violência, racismo e homofobia para criar um argumento de venda.

\section{2 "NOITE FELIZ" NAS TRINCHEIRAS DA PRIMEIRA GUERRA MUNDIAL}

A segunda propaganda a ser analisada refere-se a Sainsbury's, uma rede de supermercados do Reino Unido. A empresa divulgou uma propaganda natalina em vídeo no ano de 2014, representando cenas do cessar-fogo, não oficial, ocorrido entre soldados alemães e britânicos no meio da Primeira Guerra Mundial, fato que ficou conhecido como a trégua de Natal de 1914 - Figura 3. 


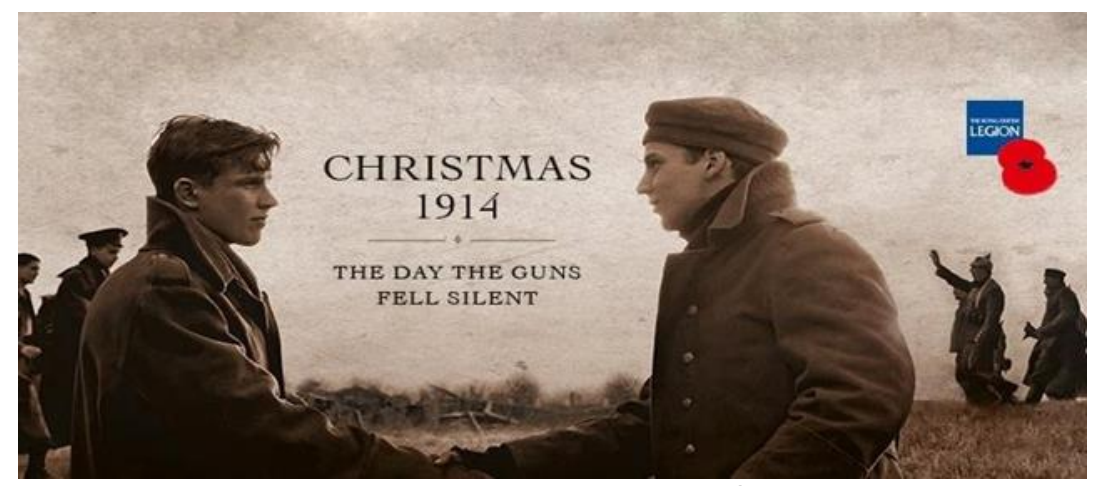

Figura 3. Propaganda da empresa Sainsbury

Fonte: The Guardian (2014).

As cenas da propaganda divulgada em formato de vídeo, sob o ponto de vista denotativo, apresentam os fatos históricos na noite de Natal de 1914. Observamos, nas trincheiras de guerra, um soldado alemão apreciando um biscoito guardado em uma caixa e um soldado britânico recebendo uma carta com uma foto e uma barra de chocolate. Em seguida, como início da trégua, os soldados alemães começam a cantar a música "Noite Feliz" e recebem resposta, em continuidade da música, dos soldados britânicos. Ao amanhecer, os dois soldados apresentados no início do vídeo se levantam das trincheiras e caminham, um em direção ao outro, em proposta de trégua. Eles e os outros que decidem acompanhar se apresentam e passam por um período de cordialidade, festividade e jogo de futebol. No momento em que a guerra se aproxima novamente, eles se despedem e trocam presentes, sendo esses 0 biscoito e 0 chocolate apresentados no começo da propaganda. Ao final, destaca-se a seguinte frase "Natal é para ser compartilhado" (tradução nossa), acompanhada da logomarca da rede de supermercados. Em seguida, a logomarca da 'The Royal British Legion, instituição com a qual a propaganda é desenvolvida em parceria. De acordo com o site institucional, essa instituição foi fundada por veteranos, após a Primeira Guerra Mundial, com o objetivo de ajudar homens e mulheres que estão a serviço das forças armadas britânicas e, também, manter a memória daqueles que deram sua vida durante a guerra.

Inicialmente, entendemos que a empresa explora uma determinada ocasião histórica em meio a acontecimentos de atrocidades da Primeira Guerra Mundial, fato que ameniza o teor sombrio da situação utilizada. A propaganda apresenta um apelo sentimental, tanto pelo fato histórico apresentado, bem como pela proximidade e relação com o Natal, data comumente relacionada a momentos agradáveis. Isso pode ser evidenciado pelos gestos que transmitem emoção ao longo do vídeo, como o sentimento que é transparecido pelo soldado britânico ao receber a foto e o chocolate, a música que remete às festividades natalinas e a frase colocada ao final do vídeo se referindo ao Natal como momento de compartilhamento. Com esse apelo, acreditamos que a empresa busque mobilizar consumidores atuais e potenciais.

Mesmo apresentando cenas com um apelo emocional, a rede de supermercados Sainsbury's tem, na nossa interpretação, o objetivo de divulgar seus produtos por meio dos mantimentos mostrados no vídeo (biscoito e chocolate), representando que seus produtos estariam presentes em todos os lugares. E mesmo em um momento de trégua, com foco emocional, o pano de fundo utilizado para comover e atrair está ligado à Primeira Guerra Mundial e suas atrocidades. Entende-se que as finalidades principais da propaganda são a divulgação da marca, o estabelecimento de sentimento positivo do consumidor em relação à empresa e à marca, atração de novos consumidores, aumento das vendas no Natal e estabelecimento de posicionamento da presença dos supermercados em diversas localidades.

Segundo a Creativity-on-line (2014), a barra de chocolate apresentada no vídeo foi colocada à venda pela rede de supermercados e o lucro revertido foi destinado para a The Royal British Legion. Assim, a empresa tenta transmitir uma postura, aparentemente, de compaixão e responsabilidade social, algo que não esconde, na nossa opinião, o foco mercadológico da ação.

\subsection{ARMAS MATAM COMO AS ONDAS DE UM TSUNAMI}

A terceira propaganda que analisamos foi divulgada em 2013, em rede social (Facebook) e no site oficial da Anistia Internacional - Figura 4. A organização possui foco na luta e no respeito pelos direitos humanos, de forma que todas as pessoas, independentemente do país, possam desfrutar dos direitos estabelecidos na Declaração Internacional dos Direitos Humanos. Segundo informações da organização, sua atuação é realizada por meio de contribuições financeiras de seus membros e simpatizantes, além de campanhas para a arrecadação de verbas. 


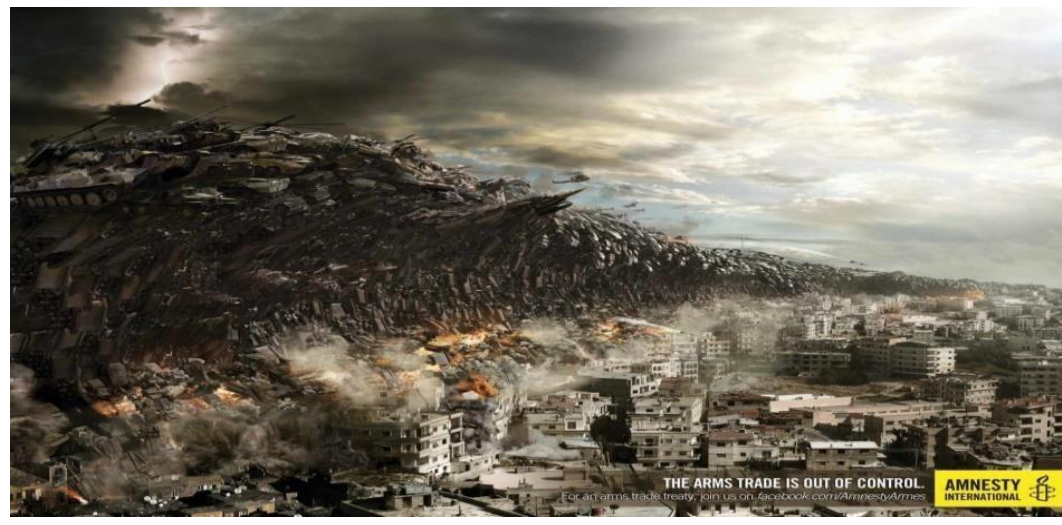

Figura 4. Propaganda da ONG Anistia Internacional

Fonte: ADNEWS (2014).

A propaganda divulgada pela Anistia Internacional remete à campanha em favor do Tratado sobre o Comércio de Armas, que, segundo a ONG, tem o objetivo de aplicação de normas rigorosas, legalmente vinculantes e globais, com relação à transferência internacional de armas, com a finalidade de deter o fluxo de armas convencionais e munições. De acordo com dados da Anistia Internacional, esse tratado foi ratificado por 50 países, entrando em vigor em dezembro de 2014.

A campanha mostra uma imagem retratando uma cidade sendo tomada por um tsunami composto por diversos tipos de armas - tanques e outros carros de guerra, armas de fogo, mísseis, helicópteros armados, entre outras. No lado direito inferior encontram-se duas frases: "O comércio de armas está fora de controle" e "Para um tratado sobre o comércio de armas" (tradução nossa), junto com o link para acesso ao Facebook da organização, além da sua logomarca.

Entendemos que a propaganda possui o objetivo de conscientização da existência e dos perigos do comércio de armas internacional, o que é retratado na intensidade da imagem de uma cidade sendo tomada por um tsunami de armas, sem formas de se defender, e também pela frase que aponta que esse comércio está fora de controle. Além disso, há um objetivo secundário, no nosso entendimento, de conseguir arrecadação de verba e simpatizantes em favor da causa.

Para alcançar esses objetivos, a organização utiliza uma tragédia para retratar as atrocidades geradas pelo descontrole do comércio de armas. $O$ tsunami - ondas gigantes provocadas por fenômenos geológicos como maremotos, movimento das placas tectônicas, deslizamento de grandes placas de gelo e outros - ficou conhecido, principalmente, pelas tragédias ocorridas no Japão e na Indonésia (2004) e no Japão (2011), devido a sua intensidade catastrófica. Na campanha que analisamos, a organização manipula o real sentido do tsunami para uma onda de armas, preservando 0 seu lado sombrio de intensidade e poder de destruição perante o local onde acontece, uma vez que o próprio assunto a ser tratado também possui um lado sombrio. Nessa visão, a campanha remete ao fato de que, assim como a tragédia do tsunami (fato conhecido por muitos) deixou milhares de vítimas, a desregulamentação do comércio de armas (fato muitas vezes ignorado pelas pessoas) mata milhares de pessoas todos os anos.

Apesar de possuir um objetivo que tende a ser positivo para a população (controle de armas), a organização utiliza-se de um fenômeno trágico, que foi responsável pela morte de milhares de pessoas e que causou sérios dados a outros tantos indivíduos e países. Entendemos que, apesar de o objetivo ser relativamente positivo para a sociedade, a ONG não se preocupou em adotar um tema que remete a tragédias, não se atentando, por exemplo, aos possíveis impactos que a lembrança dessa tragédia (tsunami) pode causar nas pessoas que a vivenciaram de perto.

\subsection{BOMBA ATÔMICA EM HIROSHIMA: NÃO DEIXE DE LER, O MUNDO NÃO PARA}

A quarta propaganda que analisamos foi divulgada pelo jornal Cape Times da cidade do Cabo, na África do Sul. O jornal divulgou uma peça em que representa uma cena, supostamente, da véspera do dia em que a bomba atômica foi lançada na cidade de Hiroshima, no Japão - Figura 5. A imagem contém três pessoas: uma mulher adulta cuidando de uma criança e outra mulher adulta ao fundo, representando o cotidiano das pessoas e da cultura japonesa. A peça também traz, no canto superior esquerdo, a data: "Domingo, 5 de agosto de 1945" (tradução nossa); e no canto inferior direito, a frase: "O mundo pode mudar em um dia. Não perca sua edição diária de notícias em profundidade" (tradução nossa), junto com o nome do jornal Cape Times. 


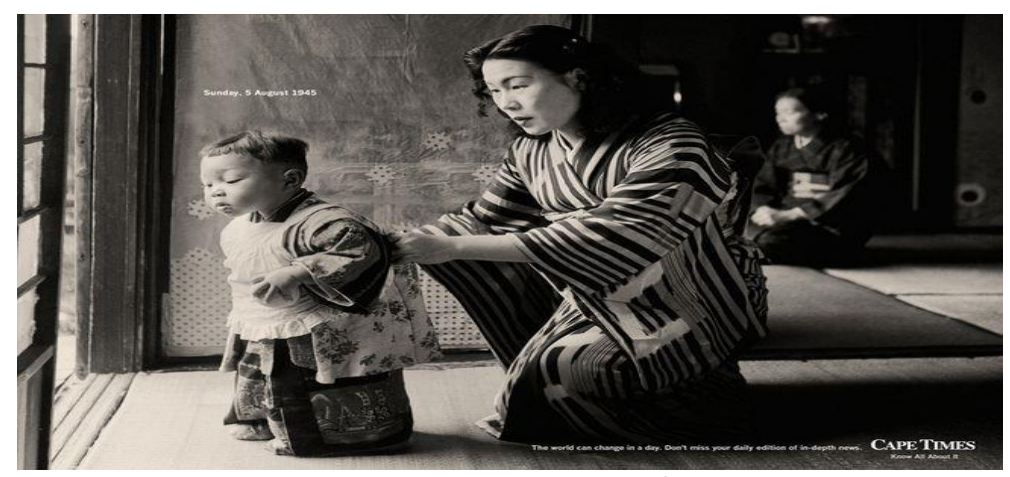

Figura 5. Propaganda do Jornal Cape Times Fonte: ADNEWS (2014).

A partir da nossa interpretação, a propaganda divulgada faz alusão ao fato de que o mundo pode mudar rapidamente ("em um dia") e que, por isso, quem deseja estar informado sobre as mudanças diárias e as notícias da atualidade deveria acompanhar as edições diárias do jornal. Esse fato é subentendido na campanha que mostra a véspera do ataque da bomba atômica, feito pelos Estados Unidos ao Japão, evidenciando a vida cotidiana no dia anterior à tragédia que matou milhares de moradores de Hiroshima. Além disso, o jornal remete a uma ideia de que aqueles que não leem suas notícias perderão os acontecimentos, como se essa fosse a única ou principal fonte de informação disponível.

A questão aqui abordada é que, para conseguir a visibilidade da campanha e o objetivo do impacto em relação às rápidas mudanças, o jornal se utilizou de uma atrocidade (bomba atômica em Hiroshima) como pano de fundo. Entendemos que o principal objetivo da campanha é vender os jornais, sugerindo que os consumidores não podem ficar nenhum dia sem se atualizar pelos periódicos da organização, pois podem perder informações essenciais, inclusive para as suas vidas.

Além dessa propaganda, o jornal também veiculou outras cenas com teor semelhante, utilizando-se de outras atrocidades e grandes acontecimentos. Isso sugere o poder de atração desses fatos trágicos e a relação que a organização faz com o seu posicionamento frente aos seus consumidores. Também mostra que a organização tenta manipular o real sentido de uma atrocidade, que envolve atos de guerra, em prol de uma campanha com objetivos de autopromoção e mercadológicos.

Essa propaganda também busca incorporar na sociedade um imperativo em torno de notícias e informações atualizadas a todo instante, com o contraponto do indivíduo se tornar desatualizado, atrasado ou obsoleto, caso não acompanhe esse processo. Novamente, vemos a manipulação de uma tragédia que comoveu o mundo e afetou parte significativa da população japonesa com a justificativa mercadológica de melhorar os resultados da organização, mesmo que isso impacte em lembranças traumáticas e situações desagradáveis para parte da população, evidenciando, na nossa opinião, o lado obscuro da organização.

\subsection{EM CASO DE ATAQUE TERRORISTA, TENHA BONS SONHOS}

No quinto caso, nós observamos a divulgação da empresa Ortobom, originalmente brasileira, mas que também atua no mercado internacional. Essa empresa trabalha na produção e na comercialização de colchões. A propaganda divulgada apresenta um calendário, especificamente no mês de setembro, sendo o dia 11 destacado em vermelho, em fundo claro, o que confere destaque à data. Ao lado do calendário encontramos a seguinte frase: "Há sempre algo que tira o seu sono. Escolha bem o seu colchão" (tradução nossa), enquanto no canto inferior direito aparece a logomarca da empresa - Figura 6. 


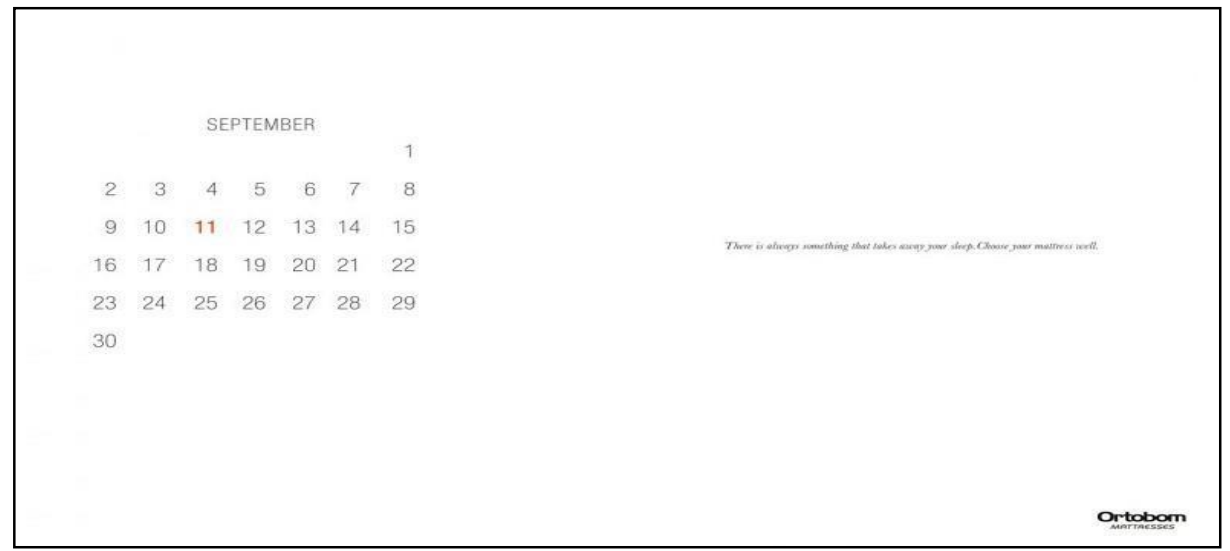

Figura 6. Propaganda da Ortobom

Fonte: Hypescience (2016).

Com essa publicação, o objetivo aparente é divulgar o produto (colchões) da empresa, com o intuito de um possível aumento das vendas. No entanto, para alcançar esse objetivo, a organização utiliza 0 ataque ao World Trade Center, ocorrido em 11 de setembro de 2001, na cidade de Nova lorque, nos Estados Unidos, cuja autoria foi atribuída à organização islâmica Al-Qaeda, que matou quase três mil pessoas e impactou na vida de milhares de pessoas não apenas no país que sofreu 0 atentando, mas em diversas partes do planeta.

Na propaganda, entendemos que a manipulação do atentado subverte o seu lado sombrio - que culminou na morte de milhares de pessoas e impactou a vida de milhões de indivíduos nas mais diversas localidades - para uma simples preocupação que pode "tirar o sono" das pessoas e que, para amenizar esses problemas, sugere que os consumidores devem escolher um produto (colchão) da empresa, para que esse produto alivie os seus problemas "cotidianos".

Vislumbramos, novamente, o dark side das organizações, que chegam a minimizar um fato bastante sério ataque terrorista - em prol dos seus objetivos mercadológicos. A propaganda gerencia e ameniza a gravidade do ocorrido, fazendo apenas uma menção à data do acontecimento, sem imagens ou frases relativas ao fato, para que se torne uma pequena preocupação que possa ser resolvida com um bom colchão, especificamente da marca Ortobom. Contudo, para isso, ignoram o sofrimento das pessoas que vivenciaram essa tragédia, desconsideram as mortes ocorridas e os diversos impactos originados a partir desse ataque terrorista que afetaram negativamente diversas pessoas.

\subsection{EM CASO DE MORTE, O GOVERNO É SOLIDÁRIO}

Por fim, analisamos uma propaganda que foi divulgada pelo governo de Minas Gerais, em TV aberta, em dezembro de 2015, a respeito do rompimento da Barragem Fundão de rejeitos, da Mineradora Samarco, na região de Mariana, Minas Gerais, ocorrido em 5 de novembro de 2015. A propaganda foi veiculada por vídeo e apresenta o seguinte discurso:

2015 termina com uma tragédia sem precedentes em Minas Gerais. A solidariedade de todos ajuda a diminuir a dor de quem perdeu tudo. Mas, para recuperar o meio ambiente e a dignidade das vítimas é preciso fazer mais. $O$ governo do estado trabalha desde a primeira hora em todas as comunidades que foram atingidas ao lado da população e dos prefeitos. Na saúde criou uma força-tarefa para agilizar 0 atendimento. Os bombeiros, a polícia e a Defesa Civil permanecem no trabalho de buscas e auxílio às vítimas. Em parceria com o Ministério Público, o governo do estado já abriu um inquérito para apurar as responsabilidades e está agindo judicialmente para prevenir e evitar novos desastres. Acesse o site para saber como ajudar. É um momento difícil para todos, mas o governo está presente, trabalhando para recuperar e revitalizar a bacia do Rio Doce. Juntos vamos superar esse desafio. Minas Gerais, governo de todos (Governo De Minas, 2015).

Ao longo do primeiro momento do discurso, tem-se a uma imagem aérea do local da tragédia, com a informação "Bento Rodrigues - Mariana-MG", abaixo e no centro da tela - Figura 7. A imagem se aproxima para onde uma mulher faz o discurso enquanto caminha pelo local. No segundo momento, a imagem da tragédia cede lugar para um fundo cinza, destacando de forma escrita o discurso oral, e, no canto superior esquerdo, a marca do Governo de Minas Gerais e a frase: "Minas Gerais, todos por Mariana". No terceiro momento do discurso, a cena volta para o local da tragédia, com a 
mesma mulher caminhando, e com o site www.todospormariana.mg.gov.br colocado abaixo e no centro da imagem, finalizando com a logomarca do governo do estado: "Minas Gerais, Governo de todos".

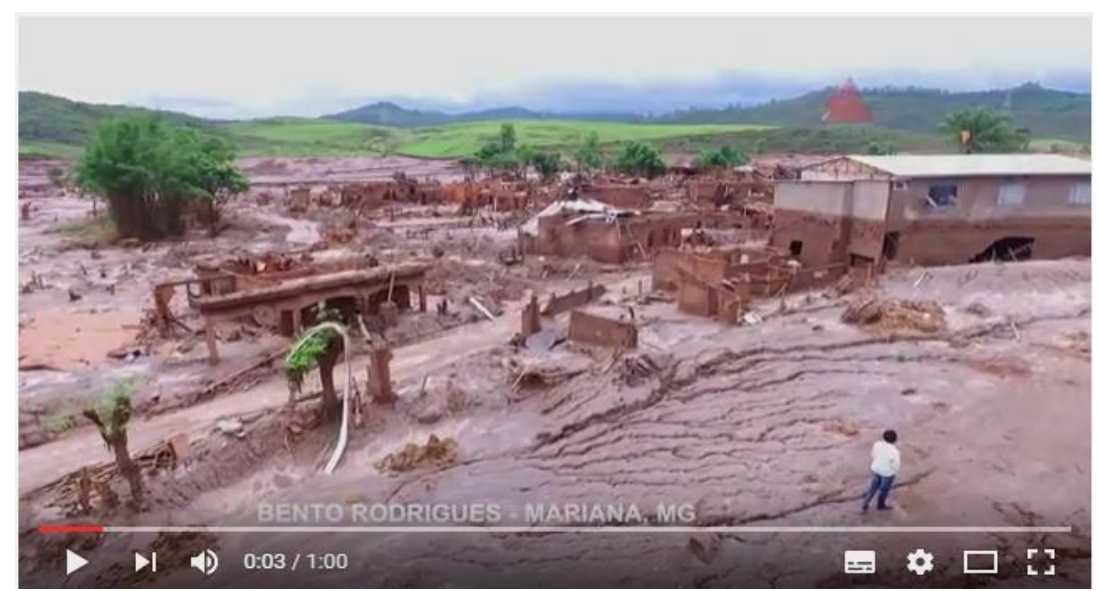

Figura 7. Propaganda do Governo de Minas Fonte: bhaz.com.br

Seguindo uma visão conotativa, percebemos que a propaganda divulgada um mês após a tragédia traz a público, de modo oficial, pelo Governo Estadual, os acontecimentos trágicos na região de Mariana e as ações realizadas pelo governo estadual em relação ao ocorrido. A propaganda aborda o assunto em um tom informativo e prestativo. Informativo, pois detalha as principais ações tomadas pelo governo até o momento da publicação da propaganda, dentro de um contexto de responsabilidade social, delineando ações de diversos departamentos, como a criação de uma forçatarefa, o trabalho de bombeiros e ações da Polícia e Defesa Civil, mostrando obras em prol da saúde à assistência e à segurança das vítimas. Também é evidenciado o trabalho jurídico na responsabilização pelo ocorrido, além do pensamento nas formas de recuperação dos danos ambientais e prevenção de possíveis futuros danos. Na vertente prestativa, é ressaltado o fato de ser uma tragédia sem precedentes e da necessidade e da importância da solidariedade de todos, mas que isso não seria o suficiente para a recuperação ambiental e da dignidade das vítimas, e, nesse contexto, entra a "prestatividade" do governo.

Assim, nessa interpretação, o governo transmite a realização de suas atividades diante do ocorrido, tendo como pano de fundo a tragédia do rompimento da barragem. Percebemos, sob um olhar crítico, a utilização da tragédia como promoção governamental, como se as atitudes tomadas por parte do governo fossem adicionais às suas atividades e não como uma obrigação diante da situação. Dessa forma, tem-se a necessidade de reafirmar o apoio governamental desde a primeira hora, em diversas áreas que precisavam de auxílio. A propaganda possui um apelo de transmitir informações à população sobre o ocorrido e os procedimentos que estavam sendo realizados, mas, também, possui um pano de fundo de promoção de atitudes governamentais que deveriam constar como básicas na prestação de serviços ao cidadão, mas que precisam ser divulgadas para aprovação e empatia da população, o que de certo modo representa uma promoção política, inclusive dos líderes do governo.

Ainda nesse último caso, ressaltamos a demora na comunicação do governo, que somente ocorreu após um mês da tragédia. Portanto, entendemos que tanto o contexto informativo como o prestativo deveriam ter ocorrido antes. A peça publicitária não destaca o período que as ações ocorreram, mas a demora na veiculação da peça sugere que 0 tom informativo não atendeu a necessidade de agilidade que se espera ao se observar uma tragédia como a ocorrida. Portanto, mesmo nesse caso que envolve uma comunicação governamental, que em tese não tem como objetivo angariar melhores resultados financeiros, o dark side da organização (Governo Estadual) está presente, ao se aproveitar de uma tragédia para se autopromover.

\section{DISCUSSÃO DOS RESULTADOS}

Diante da análise das seis propagandas, podemos considerar a compreensão do complexo de atitudes tomadas pelas organizações ao publicarem as propagandas analisadas como pertencentes ao lado sombrio das organizações. Muhr e Rehn (2014) afirmam que o elemento-chave é perceber que os lados sombrios não são representados nas organizações somente como algo a esconder, distante e de difícil controle, mas, também, como algo com o que as organizações podem se aproximar e se envolver. No entanto, os estudos a respeito desse contexto ainda são incipientes. 
A partir do exposto ao longo da pesquisa, percebemos o gerenciamento de imagens trágicas por organizações, apesar de objetivos diferentes como pano fundo. Retomando as observações de Witzki, Prado Júnior e Cardoso (2017), assim como somos influenciados por narrativas com emoções positivas, também podemos ser influenciados por associações negativas, que seria a naturalização das atrocidades. Em cada caso analisado as organizações responsáveis pela propaganda decidiram manipular as imagens de tragédias e atrocidades utilizando-se do apelo mais conveniente, considerando a situação, seja emocional, informativa, impactante ou atrativa. Contudo, em comum, identificamos o uso para fins mercadológicos das tragédias e das atrocidades que serviram de pano de fundo para as propagandas, isso sem indicar preocupação com os possíveis afetados pelo destaque dessas tragédias destacadas nos anúncios, o que foi encontrado também em Muhr e Rehn (2014). Ou seja, o objetivo comercial ou político, para o caso da propaganda governamental, se sobrepõe ao indivíduo em ambos os casos, sendo os possíveis impactos nas pessoas da lembrança e reforço desses momentos trágicos ignorados pelas organizações promotoras das propagandas.

Também compreendemos que nem todas as organizações tenham considerado os impactos que esse tipo de propaganda pode elencar, e nem que essas têm habilidades para contornar a ambiguidade nesse tipo de comunicação, uma vez que, em alguns casos, surgiram avaliações negativas por parte dos consumidores e do público em geral. Mas, mesmo nesses casos, a marca ou o nome da empresa ainda estavam como foco de atenção, alcançando, de certo modo, 0 objetivo planejado.

No entanto, ainda se deve ter atenção quanto a esse fato. Conforme é apontado por Hatch e Schultz (2000), na compreensão da imagem organizacional, não significa que ela é interpretada da mesma forma que foi criada. Assim, podem haver divergências nesse processo, pois, em muitos casos, a imagem vista não é condizente com a real intenção organizacional, podendo levar a marca ou a organização a receber aversão do público, e, principalmente, nesses casos do uso de imagens trágicas, essa aversão pode ser duradoura.

De acordo com Muhr e Rehn (2014), dependendo da estrutura em que uma atrocidade ou tragédia é introduzida, isso tem um preço, podendo representar um alto custo para a organização, inclusive para sua imagem. Mesmo com esse risco, esses fatos sombrios da sociedade são ligados à imagem organizacional, com o foco de que o retorno pode ser maior do que o risco. Essa ligação ocorre por meio da manipulação do real significado de cada fato, adequando a resposta esperada em cada situação, seja ela atenção à marca (primeiro caso), comoção e empatia com a marca (segundo caso), impacto, ética e empatia com a causa (terceiro caso), visibilidade à marca e ao serviço (quarto caso), visibilidade à marca e ao produto (quinto caso) e responsabilidade social (sexto caso).

Retomando o objetivo desta pesquisa, que é explorar de que modo as organizações gerenciam os significados de tragédias e atrocidades externas em campanhas publicitárias para atingir seus objetivos, mostramos que as tragédias e as atrocidades são utilizadas para significações diversas, conforme Figura 8. A primeira coluna apresenta o sentido denotativo (plano de expressão), a segunda o sentido conotativo (significações), a terceira coluna, o mito (crenças) e, na quarta coluna, incluímos um termo ou expressão para resumir as significações.

\begin{tabular}{|c|c|c|c|c|}
\hline & Denotação & Conotação & Mito & Significado \\
\hline 1 & $\begin{array}{l}\text { Campo de concentração } \\
\text { Dê adeus às suas calorias }\end{array}$ & $\begin{array}{l}\text { Castigo: campo de concentração } \\
\text { para queima de calorias }\end{array}$ & $\begin{array}{c}\text { É preciso ser fitness } \\
\text { Gorduras ou excessos devem } \\
\text { ser eliminados }\end{array}$ & $\begin{array}{l}\text { Castigo para } \\
\text { obesidade }\end{array}$ \\
\hline 2 & $\begin{array}{c}\text { Soldados inimigos na Primeira } \\
\text { Grande Guerra Mundial } \\
\text { compartilham chocolate e } \\
\text { biscoito Natal } 1914\end{array}$ & $\begin{array}{l}\text { Noite Feliz nas trincheiras da } \\
\text { Primeira Guerra Mundial }\end{array}$ & $\begin{array}{l}\text { O consumo pode trazer bons } \\
\text { momentos, mesmo em } \\
\text { tempos de guerra }\end{array}$ & $\begin{array}{l}\text { Felicidade na } \\
\text { guerra }\end{array}$ \\
\hline 3 & $\begin{array}{c}\text { O comércio de armas está fora } \\
\text { de controle } \\
\text { Tsunami }\end{array}$ & $\begin{array}{l}\text { Armas matam como as ondas de } \\
\text { um tsunami }\end{array}$ & $\begin{array}{c}\text { O comércio de armas é } \\
\text { incontrolável, assim como um } \\
\text { tsunami }\end{array}$ & Não às armas \\
\hline 4 & $\begin{array}{l}\text { Mulheres e crianças japonesas } \\
\text { dentro de casa } \\
\text { Domingo, } 5 \text { de agosto de } 1945 \\
\text { O mundo pode mudar em um } \\
\text { dia. Não perca sua edição } \\
\text { diária de notícias em } \\
\text { profundidade }\end{array}$ & $\begin{array}{l}\text { Bomba atômica em Hiroshima: } \\
\text { não deixe de ler, o mundo não } \\
\text { para }\end{array}$ & $\begin{array}{l}\text { Não importa o que estiver } \\
\text { acontecendo, é preciso estar } \\
\text { sempre bem informado, pois } \\
\text { quem não se informa fica } \\
\text { obsoleto }\end{array}$ & Informação é vida \\
\hline
\end{tabular}




\begin{tabular}{|c|c|c|c|c|}
\hline $\mathbf{5}$ & $\begin{array}{c}\text { Calendário marcado com a } \\
\text { data de 11/09 } \\
\text { Escolha bem o seu colchão }\end{array}$ & $\begin{array}{c}\text { Em caso de ataque terrorista, } \\
\text { tenha bons sonhos }\end{array}$ & $\begin{array}{c}\text { Não importa o que estiver } \\
\text { acontecendo, dormir é } \\
\text { possível }\end{array}$ & $\begin{array}{c}\text { Descanso em } \\
\text { tempos de terror }\end{array}$ \\
\hline $\mathbf{6}$ & $\begin{array}{c}\text { Estragos provocados pelo } \\
\text { rompimento da barragem } \\
\text { administrada pela Samarco } \\
\text { Minas Gerais, todos por Mariana }\end{array}$ & $\begin{array}{c}\text { Em caso de morte e outras } \\
\text { perdas, o governo é solidário }\end{array}$ & $\begin{array}{c}\text { O governo tem a função de } \\
\text { agir quando tragédias } \\
\text { acontecem }\end{array}$ & $\begin{array}{c}\text { Morte e } \\
\text { solidariedade }\end{array}$ \\
\hline
\end{tabular}

Figura 8. Significados das propagandas analisadas

Fonte: Dados de pesquisa

A partir desses casos analisados, percebemos também que o uso somente da imagem ou cena de uma tragédia ou atrocidade não é o suficiente, é necessário, e foi visto em todos os casos, a utilização da narrativa ou a criação de enredos em torno de cenas e acontecimentos trágicos. Segundo Muhr e Rehn (2014), observa-se, nesses casos, uma série de dispositivos discursivos projetados para narrar a atrocidade de uma maneira fluida e eficaz, na tentativa de tornála mais fácil de processar. Essas narrativas, conforme notamos, tanto foram usadas para manter o impacto e a imponência do acontecimento, como para amenizar qualquer aspecto do lado sombrio, de acordo com o objetivo gerencial que cada situação demandava.

Diferentemente das pesquisas que analisam campanhas publicitárias para investigar as associações afetivas positivas (Martins \& Medeiros, 2017; Witzki, Prado Júnior, \& Cardoso, 2017), percebemos que essa tática discursiva criada em torno de imagens e cenas se torna uma ferramenta organizacional para gerenciar o lado sombrio e os significados de acontecimentos trágicos, manipulando esses significados para tornar essas cenas fontes de recursos para comunicação mercadológica, a exemplo do que Featherstone (1995) afirmou sobre a manipulação de imagens para fins comerciais. A apropriação de simbolismos de imagens e seus textos acontece em geral, conforme Silva e Chaves (2017) identificaram no setor supermercadista, com associações afetivas às imagens de propagandas do setor. E organizações de diversas formas e com diferentes objetivos têm utilizado essa estratégia, até mesmo como forma de manter um posicionamento duradouro.

Essa ferramenta de gerenciamento de imagem, na nossa interpretação, cria enredos ou significados a serem reproduzidos socialmente, como (1) castigo para a obesidade, enredo referenciado pela primeira propaganda, ao associar perda de peso com um campo de concentração/extermínio nazista; (2) felicidade na guerra, ao mostrar 0 "compartilhamento de produtos, desde que seja Sainsbury's", fazendo alusão de momentos de compartilhamento em meio à guerra, se referindo aos produtos da própria marca; (3) não às armas mostrado na terceira propaganda, evidenciando o poder de destruição do tsunami e do comércio de armas sobre a sociedade e buscando simpatizantes para o fim desse tipo de transação; (4) informação é vida resume o enredo no quarto caso, "o mundo pode mudar em um dia. Não perca sua edição diária de notícias", o qual imprime uma necessidade por notícias todos os dias; (5) na quinta propaganda, o significado descanso em tempos de terror é evidenciado na frase usada também para a construção do enredo "há sempre algo que tira o seu sono", fazendo alusão a grandes tragédias que podem tirar o sono, problema que pode ser resolvido com a escolha de um bom colchão. E, no último caso, (6) morte e solidariedade é 0 significado que resume a chamada "todos por Mariana", que também se comporta como um enredo a ser reproduzido socialmente, em uma tentativa de associar a imagem da organização, nesse caso, o governo, à responsabilidade social (Oliveira, Correia, \& Gomez, 2016).

Esses enredos e essas narrativas são repassados socialmente, influenciando a criação da realidade (Gioia, 1986) e, muitas vezes, sem uma visão crítica do seu conteúdo denotativo e dos objetivos que podem existir por trás dessas construções, tanto para narrativas de felicidade (Martins \& Medeiros, 2017; Witzki, Prado Junior, \& Cardoso), bem como aquelas que lembram tragédias e atrocidades ocorridas. Nesse sentido, remetemos a Muhr e Rehn (2014) sobre 0 dark side do marketing, quando percebemos a existência de ambiguidade nas mensagens e comunicações, abordando temas sombrios da sociedade, temas que se enquadram em situações que causaram sérias perdas sociais e ambientais, e que, no entanto, não são refletivas quando se tornam meros cenários para propagandas, ignorando, inclusive, os indivíduos que foram impactos, seja de forma direta ou indireta, por esses acontecimentos.

Assim, este estudo sugere, corroborando com Muhr e Rehn (2014), que mesmo pertencendo a um lado sombrio, as organizações se valem de suas capacidades e habilidades para interagir com fenômenos trágicos, aproximando-os do contexto organizacional, ou seja, as discursivas, para atingir seus objetivos organizacionais, independentemente dos impactos dessas ações. 


\section{CONSIDERAÇÕES FINAIS}

Em nossa pesquisa, sobre o modo como as organizações exploram tragédias e atrocidades em suas campanhas publicitárias, mostramos que essas dirigem esforços para gerenciar os significados de eventos trágicos, mesmo que esses acontecimentos não tenham nenhuma relação com elas. Nas seis propagandas analisadas, identificamos que as atrocidades são relacionadas nas propagandas com ideias de consumo, estilo de vida e outras exigências culturais, como a orientação para a flexibilidade em tempos de mudança.

Ao associar textos e imagens, a análise estrutural-semiológica realizada apontou para os sentidos conotativo, denotativo e os mitos que compõem a comunicação das organizações, revelando alguns padrões sociais cultuados na sociedade contemporânea e, ao mesmo tempo, aponta para a necessidade de reflexões sobre o uso de tais fenômenos como forma de associação com a imagem da empresa e seus produtos.

Os resultados apresentados têm implicações teóricas e práticas. Além de contribuir para estimular pesquisas sobre o tema, contribuímos por apontar a aproximação de atrocidades e tragédias ao contexto organizacional, mesmo que a organização não participe do fenômeno. Isso porque, conforme a literatura sobre o tema, a fronteira entre a imagem e a identidade é tênue e, portanto, o gerenciamento da identidade e da imagem é um processo relacionado. Quanto aos aspectos práticos, os resultados contribuem para que gestores e profissionais que desenvolvem campanhas publicitárias fiquem atentos às múltiplas interpretações que podem surgir por parte do público interno e externo, pois essas podem ser associadas a emoções positivas, como também podem naturalizar tragédias e atrocidades. Além disso, essas interpretações influenciam diretamente a percepção que o mercado terá em relação às organizações. Isso porque, ao utilizar tragédias e atrocidades nas suas campanhas publicitárias, as empresas parecem desconsiderar que sobreviventes aos acontecimentos, bem como familiares e amigos das vítimas, estarão sujeitos a reviver a violência, a agonia e 0 desespero, entre outras emoções. Como limitações, apontamos a busca por propagandas que pudessem ter sua fonte comprovada, visto que algumas das propagandas utilizadas não possuem publicação recente.

Outras implicações podem resultar de futuras pesquisas que se orientem para explorar os significados de atrocidades e tragédias na utilização de propagandas, como: analisar a opinião de consumidores quanto à utilização de atrocidades e tragédias em propagandas, investigar a opinião de profissionais de marketing sobre essa utilização e realizar uma análise crítica de uma campanha publicitária que utiliza esses fenômenos e os padrões culturais a eles associados.

\section{REFERÊNCIAS}

Adnews. (2014). 10 campanhas que utilizam tragédias históricas como mote. Disponível em: < http://adnews.com.br/publicidade/10-campanhas-que-utilizam-tragedias-historicas-como- mote.html > Acesso em: 10 abr. 2016.

Barbosa, T. G. (2008). Imagem e Gerenciamento de Imagem - Um estudo sobre o museu Inhotim. 139 f. Dissertação (Mestrado em Administração) Faculdade Novos Horizontes, Belo Horizonte. Recuperado em 12 mai., 2016 de http://www.unihorizontes.br/banco_dissertacoes/150620091529328713.pdf.

Barbosa, V. (2018). Terra em fúria - os desastres naturais que castigaram o mundo em 2018. REVISTA EXAME. Recuperado em 20 jun., 2019, de https://exame.abril.com.br/mundo/terra-em-furia-os-desastres-naturais-que-castigaram-o-mundo-em-2018/.

Barthes, R. (2006). Elementos de semiologia. Tradução de Izidoro Blikstein. São Paulo: Editora Cultrix.

Bauer, M. W., \& Gaskell, G. (2002). Pesquisa Qualitativa com Texto, Imagem e Som. Um manual prático. Petrópolis: Vozes.

Bhaz. (2013). Governo de Minas: 100 milhões em publicidade para explorar tragédias e desconstruir o passado. Recuperado em 10 abr., 2016 de http://bhaz.com.br/2016/01/13/governo-de-minas- 100-milhoes-em-publicidadepara-explorar-tragedias-e-desconstruir-o-passadol.

Boddy, C. R. (2006). The dark side of management decisions: Organisational psychopaths. Management Decision, $44(1), 1461-1475$.

Boyce. M. E. (1996). Organizational story and storytelling: a critical review, Journal of Organizational Change Management, 9(5), 5-26. 
Brandão, J. (2019). A indiferença humana diante do excess de tragédias. EMPODERADxS. Recuperado em 10 jul., 2019 de https://empoderadxs.com.br/2019/02/14/a-indiferenca-humana-diante-do-excesso-de-tragedias/.

Business Insider. (2016). 10 ads exploiting the 9/11 attacks. Recuperado em 10 abr., 2016 de http://www.businessinsider.com/10-ads-exploiting-the-911-attacks-2012-9?op=1.

Carr, J. M., \& Schreuer, R. (2010). Connecting the dots. Marketing Management, 19(1), $26-32$.

Creativity-Online. (2016). Is This Christmas Ad a 'Dangerous and Disrespectful Masterpiece'? Recuperado em 22 jun., 2016 de http://creativity-online.com/work/sainsburys-official-christmas-ad/37838.

Daunt, K. L., \& Greer, D. A. (2017). The dark side of Marketing: Introduction to the special issue. Journal of Marketing Management, 33(15-16), 1231-1235.

Dootson, P., Lings, I., Beatson, A., \& Johnston, K. A. (2017). Deterring deviant consumer behaviour: when 'it's wrong, don't do it' doesn't work, Journal of Marketing Management, 33(15-16), 1355-1383.

Featherstone, M. (1995). Cultura de consumo e pós-modernismo. São Paulo: Nobel.

Freitas, M. E. de. (2000). Contexto social e imaginário organizacional moderno. Rev. adm. empresas, 40(2), 6-15.

Gioia, D. A. (1986). Symbols, scripts, and sensemaking: creating meaning in the organizational experience. In H. P. Sim, \& D. A. Gioia (Eds.). The thinking organization (pp. 49-74). San Francisco: Jossey-Bass Publishers.

Golf-Papez, M., \& Veer, E. (2017). Don't feed the trolling: rethinking how online trolling is being defined and combated, Journal of Marketing Management, 33(15-16), 1336-1354.

Hatch, M., \& Schultz, M. (1997). Relation between organizational culture, identity and image. European Journal of Marketing, 31(5/6), 356-365.

Hatch, M.J., \& Schultz, M. (2000). Scaling the tower of Babel: Relational differences between identity, image and culture in organizations. In M. Schultz, M. J. Hatch, \& M. H. Larsen. The expressive organization: linking identity, reputation and corporate brand. Oxford Press.

Hatch, M. J., \& Schultz, M. (2002). The Dynamics of Organizational Identity. Human Relations, 55.

Heath, T., Cluley, R., \& O'malley, L. (2017). Beating, ditching and hiding: consumers' every day resistance to marketing, Journal of Marketing Management, 33(15-16), 1281-1303.

Hogan, R., Raskin, R., \& Fazzini, D. (1990). The dark side of charisma. In K. E. Clark, \& M. B. Clark (Eds.), Measures of leadership (pp. 343-354). West Orange, NJ, US: Leadership Library of America.

Hypescience. (2016). 10 propagandas absurdas que tentaram lucrar com tragédias. Recuperado em 10 abr., 2016 de http://hypescience.com/10-propagandas-absurdas-que-tentaram-lucrar-com-tragedias/.

Jatahi. P. J. de C. (2004). O poder simbólico e o gerenciamento de impressões em organizações públicas: a construção do mito da eficácia do Banco Central na administração da política econômica. Cadernos EBAPE.br, 2(3). Recuperado em 18 mai., 2016 de http://www.scielo.br/pdf/cebape/v2n3/v2n3a09.pdf.

Jornal The National. (2016). Dubai fitness firm The Circuit Factory apologises over Auschwitz joke. Recuperado em 14 jun., 2016 de http://www.thenational.ae/news/uae-news/dubai-fitness-firm-the-circuit-factory-apologises-overauschwitz-joke.

Khan, F. R., Munir, K. A., \& Willmott, H. (2007). A dark side of institutional entrepreneurship: Soccer balls, child labour and postcolonial impoverishment. Organization Studies, 28(2), 1055-1077.

Linstead, S., Marechal, G., \& Griffin, R. (2014). Theorizing and Researching the Dark side of Organization. Organization 
studies, 35(2), 165-188.

Longo, C. S., \& Narita, S. (2014). Um Corpus que Fala": Apontamentos para uma Revisão Técnica da Análise de Conteúdo. Web-Revista SOCIODIALETO, 4(12), 42-60.

Magalhães, A. F., \& Paula, C. R. de A. (2016). Reflexões sobra a "Inclusão" de Minorias Sociais nas Organizações de Trabalho: Uma Análise Semiótica de uma Estratégia de Recrutamento de Pessoas do McDonald's Brasil. 2016, Belo Horizonte. Anais do Encontro de estudos Organizacionais da ANPAD, 9, Belo Horizonte.

Martins, R. M., \& Medeiros, C. R. O. (2017). A fantástica fábrica da felicidade: storytellings e simbolismo nas campanhas publicitárias da Coca-Cola. Perspectivas contemporâneas, 12(1), 107-124.

Muhr, S. L., \& Rehn, A. (2014). Branding Atrocity: Narrating Dark sides and Managing Organizational Image, Organization Studies, 35(2), 209-231.

Oliveira, V. M., Correia, S. E. N., \& Gómez, C. R. P. (2016). Cultura de Consumo, Sustentabilidade e Práticas Empresariais: Como as Empresas Podem Contribuir para Promover o valor Simbólico da Sustentabilidade nas Atividades de Consumo? Revista de Gestão Ambiental e Sustentabilidade, 5(1), 61-77.

Pancer, E., Mcsahe, L., \& Poole, M. (2017). Schadenfreyde And product failures: the role of product desevingness and product status. Journal of Marketing Management, 33(15-16), 1236-1255.

Penn, G. (2002). Análise semiótica de imagens paradas. In: BAUER, M. W.; GASKELL, G. Pesquisa Qualitativa com Texto, Imagem e Som. Um manual prático. Petrópolis: Vozes.

Pinheiro, G. (2019). Os eventos climáticos extremos são o novo normal no Brasil. NEXO. Recuperado em 25 jun., 2019 de https://www.nexojornal.com.br/ensaio/2019/Os-eventos-clim\%C3\%A1ticos-extremos-s\%C3\%A30-o-novonormal-no-Brasil.

Revista Exame. (2016). 5 anúncios com alusão ao atentado de 11 de setembro. Recuperado em 10 abr., 2016 de http://exame.abril.com.br/marketing/noticias/5-anuncios-que-abordaram-o-ataque-as-torres-gemeas-em-11-desetembro\#5.

Scussel, F. B. C., \& Dellagnelo, E. H. L. (2018). O Peso do Discurso: A Representação da Mulher Plus Size em Campanhas Publicitárias de Lingerie no Brasil. Revista Brasileira de Marketing, 17(6), 931-945.

Silva, I. G. B., \& Chaves, E. P. S. (2017). Análise da Propaganda do Varejo Supermercadista no Brasil: Um Estudo da Semiótica dos Maiores Players do Mercado. Revista de Administração IMED, 7(2), 124-138.

Tavares, I. (2013). Desastres não são naturais, mas socialmente construídos', diz especialista”. Notícias UOL. Ambiente. Recuperado em 25 jun., 2019 de https://noticias.uol.com.br/meio-ambiente/ultimasnoticias/redacao/2013/09/11/mudancas-climaticas-intensificam-desastres-naturais-no-brasil.htm.

The Guardian. (2014). Sainsbury's Christmas advert recreates first world war truce. Recuperado em 14 jun., 2014 de https://www.theguardian.com/media/2014/nov/13/sainsburys-christmas-advert-recreates-first-world-war-truce.

Uol. Trégua Primeira Guerra Mundial. Recuperado em 14 jun., 2016 de http://adct.uol.com.br/2014/11/20/tregua-primeiraguerra- mundial/.

Vaughan, D. (1999). The dark side of organizations. Annual Review Sociology, 25, 271-305.

Vince, R., \& Mazen, A. (2014). Violent Innocence: A Contradiction at the Heart of Leadership. Organization Studies, 35(2), 189-207.

Vries, M. F. R. K. de. (1985). The dark side of Entrepreneurship. Harvard Business Review, 63(6), 160-167.

Weeks, C. S., O'connor, P. J., \& Martin, B. A. S. (2017). When Ambush marketing is beneficial to sponsorship awareness: creating sponsor distinctiveness using exclusivity and brand juxtaposition. Journal of Marketing Management, 33(1516), 1256-1280. 
Witzki, F. L., Prado Junior, T., \& Cardoso, M. (2017). Narrativas da felicidade mediadas pelas práticas do consumo. Revista Eletrônica Internacional de Economia Política da Informação da Comunicação e da Cultura, 19(2), 122-135.

Zolfagharian, M., \& Yasdanparast, A. (2017). The dark side of consumer life in the age of virtual and mobile technology. Journal of Marketing Management, 33(15-16), 1304-1335. 